\title{
An overview of the cytological, physiological, genetic and morphological effects of Mentha longifolia essential oil
}

\author{
Sedat BOZARI ${ }^{1} \mathscr{\&}$, Güleray AĞAR ${ }^{2}$, Derya EFE ${ }^{3}$, Ömer BİNGÖL ${ }^{4}$ \\ ${ }^{1}$ Mus Alparslan University Faculty of Science, Department of Molecular Biology and Genetics, Mus 49250, Turkey \\ ${ }^{2}$ Ataturk University, Faculty of Science, Department of Biology, Erzurum 25240, Turkey \\ ${ }^{3}$ Giresun University, Espiye Vocational School, Department of Herbal and Animal Production, Giresun, 2800 , \\ Turkey \\ ${ }^{4}$ Yuzuncu Y1l Üniversity, Faculty of Science, Department of Biology, Van, 65000, Turkey \\ $\triangle$ : sedatbozari@gmail.com, (iD) ${ }_{1} 0000-0001-5265-2236$, (D) ${ }_{2}^{2} 0000-0002-8445-5082,{ }_{3} 0000-0003-3554-1790$, (iD $40000-$ \\ 0001-8007-4621
}

Received (Geliş ): 01.12.2021Ｒevision (Düzeltme): 16.12.2021Ａccepted (Kabul): 22.12.2021

\begin{abstract}
The present study was aimed to impress the cytological, physiological, genetic, and morphological effects of the essential oil obtained by hydro-distillation from Mentha longifolia (L.) HUDSON (L.) HUDSON on maize seeds. These naturally occurred compounds can be used instead of synthetic chemicals. To determine the biological activity of the essential, they were applied to Zea mays L. seeds at different concentrations. It was observed that the germination rate and mitotic division of the root tips were decreased with the increasing of the concentrations. Genomic stability was established by RAPD and the genetic differences between concentrations with the AFLP technique. The alterations of RAPD and AFLP profiles did not support germination rate and mitotic index results while supporting each other. To determine the effects of the volatile on gene expression, the soluble protein level, and plant growth regulators levels were measured and the changes in the protein profile were determined by SDSPAGE analyses. The independent changes were observed at plant growth regulators, soluble protein level, and protein profiles. It was determined that the oils showed independent effects at different parameters against to maize seeds. It was concluded that different mechanisms have been considered by maize seeds to protect seeds from exogenous substances.
\end{abstract}

Keywords: Allelopathy, AFLP, Essential oil, Lamiaceae, Plant growth regulator, RAPD, SDS-Page

$\ddot{O} \mathbf{Z}$

\section{Mentha Longifolia Esansiyel Yağlarının Sitolojik Fizyolojik Genetik ve Morfolojik Etkilerine Genel Bir Bakış}

$\mathrm{Bu}$ çalışma, Mentha longifolia (L.) HUDSON (L.) HUDSON'dan hidrodistilasyon ile elde edilen uçucu yağların mısır tohumlarına karşı sitolojik, fizyolojik, genetik ve morfolojik etkilerini belirlemeyi amaçlamıştır. Doğal olarak oluşan bu bileşikler, sentetik kimyasallar yerine kullanılabilir. Uçucu yağlar, biyolojik aktivitelerinin belirlenmesi için, Zea mays L. tohumlarına farklı dozlarda uygulandı. Uygulanan yağların dozlarının artmasıyla kök ucu uzunluğunun, çimlenme hızının ve mitotik bölünmenin azaldığı gözlemlendi. Yağların neden olduğu genomik stabilite RAPD, dozlar arasındaki genetik farklılıklar ise AFLP tekniği ile belirlendi. RAPD ve AFLP profillerindeki değişikliklerin benzer olduğu ancak çimlenme oranı ve mitotik indeks sonuçlarıyla uyuşmadığı görüldü. Uçucu bileşenlerin gen ekspresyonu üzerindeki etkilerini belirlemek için çimlendirilen tohumların çözünür protein seviyesi ve bitki büyüme düzenleyicileri seviyeleri ölçüldü. Protein profillerindeki değişiklikler SDS-PAGE ile belirlendi.

Bitki büyüme düzenleyicileri seviyeleri, çözünür protein seviyesi ve protein profillerinde birbirinden bağımsız değişimler gözlendi. Uygulanan uçucu yağların mısır tohumları üzerine farklı parametrelerde birbirinden bağımsız etkiler gösterdiği belirlendi. Çimlenen tohumların, ekzojen maddelerden korunmak için farklı mekanizmalar geliştirdiği kanısına varıldı.

Anahtar Kelimeler: Allelopati, AFLP, Bitki büyüme düzenleyicileri, Lamiaceae, RAPD, SDS-Page, Uçucu yağlar

\section{INTRODUCTION}

In recent years, one of the most serious problems is starvation, which treats millions of people all over the world. Therefore, various researches have been carried out to use the agricultural lands efficiently and to increase yield production [1, 2]. Every year, a substantial part of the yield has been lost due to plant diseases caused by fungi, bacteria and, viruses or weeds. Up to now, many synthetic chemicals and herbicides have been used to protect the crops from undesirable effects of microorganisms and harmful weeds. However, recent studies have exhibited that indiscriminate use of synthetic chemicals and herbicides in agricultural lands cause undesirable effects on environmental health because of the accumulation of toxic residues in agricultural products and their slow biodegradation [3, 4]. This situation has forced the researchers to discover new natural substances from various sources like 
medicinal plants possessing antimicrobial potential against plant diseases and allelopathic effects against weeds $[5,6]$. Among many medicinal plants, Lamiaceae species and their products such as essential oils, have been widely studied for their biological activities. The Lamiaceae is a family of plants having about 233 genera and 6900 species [7]. The phenolic compounds, such as rosmarinic acid, caffeic acid, ferulic acid, chlorogenic acid, luteolin, apigenin, genkwanin, quercitrin, rutin, epicatechin, and catechin are rich in Lamiaceae species $[4,8,9]$. It has been clarified that they have many biological activities, such as anti-inflammatory, anticancer, antifungal, antimicrobial, and allelopathic activities due to their components [10-12]. Mentha longifolia L. Hudson ssp. longifolia, a member of Lamiaceae, is a well-known aromatic and medicinal plant. It has been used in folk medicines to treat many illnesses because of its antispasmodic, expectorant, diuretic, antimicrobial activities as is stated in the relevant literature $[13,14]$. In the light of these researches, it seems Mentha longifolia L. Hudson ssp. longifolia, to be a good candidate for a natural biopesticide agent. Nevertheless, probable side effects on the main agricultural products should be completely determined not to cause damage to the living.

In this research, it was aimed to evaluate the biological effects of Mentha longifolia L. Hudson ssp. longifolia, which has been previously proven to be allelopathic and antimicrobial. To this end, the essential oil was applied to Zea mays L. seeds at different concentrations. The germination rates and mitotic divisions of the root tips, the soluble protein levels, and plant growth regulator levels of samples and control groups were determined. In addition, RAPD-PCR (randomly amplified polymorphic DNA-PCR) and AFLP-PCR (amplified fragment length polymorphismPCR), and SDS-PAGE analyses were carried out for the determination of genotoxic and physiological effects of essential oil of Mentha longifolia L. Hudson ssp. longifolia on Zea mays L. seeds.

\section{MATERIAL AND METHODS}

\section{Plant material}

Plant material was collected at the flowering stage from the eastern part of Erzurum in Turkey. Identification of the plant materials was confirmed by a plant taxonomist, Prof. Dr. Yusuf KAYA, in the Department of Biology, Ataturk University, Erzurum, Turkey.

\section{Isolation of the essential oil and GC-MS analysis}

Plant samples were dried in a canopy room. The aerial parts (leaves, flowers, and stems) of the plants were powdered with a blender and then subjected to water distillation for 2-3 $\mathrm{h}$ in a Clevenger-type apparatus (Thermal Laboratory Equipment, TURKEY). The essential oils were stored at $+4^{\circ} \mathrm{C}$ for further studies.

The essential oils were analyzed by using a Thermofinnigan Trace GC/Trace DSQ/A1300, (E.I Quadrapole) equipped with an SGE-BPX5 MS capillary column (30 m X $0.25 \mathrm{~mm}$ i.d., $0.25 \mu \mathrm{m})$. The components were identified based on the comparison of their relative retention time and mass spectra with those of standards, Wiley $7 \mathrm{~N}$ library data of the GC-MS system, and literature data. The results were also confirmed by the comparison of the compound's elution order with their relative retention indices on non-polar phases reported in the literature.

\section{Seed germination with essential oil treatment}

A total of 15 Z. mays seeds, which are possibly equally sized, were superficially sterilized with $5 \%(\mathrm{w} / \mathrm{v})$ $\mathrm{NaOCl}$ for 6-10 min, germinated and exposed to four different concentrations $(0.1,0.2,0.4$ and $0.8 \mu \mathrm{L} / \mathrm{mL})$ of essential oils dissolved in Tween 20 [12]. The control group was formed by using only double-distilled water with Tween 20 without Essential oil (EO). Three replicates were performed for each experimental group and control group.

\section{Genomic DNA isolation and application of molecular methods}

After 7-10 days, approximately $15 \mathrm{mg}$ of germinated part of the seeds was collected and snap-frozen in liquid nitrogen. DNA isolation of samples was carried out according to the method described by Liu et. al. [15].

16 primers were used for RAPD-PCR reactions. The PCR reactions were accomplished in the tubes containing reaction mixtures $(3 \mu \mathrm{L} 10 \mathrm{X}$ buffer, $1.2 \mu \mathrm{L}$ $10 \mathrm{mM}$ dNTPs, $1.2 \mu \mathrm{L} 25 \mathrm{mM} \mathrm{MgCl}_{2}, 2.0 \mu \mathrm{L} 5 \mu \mathrm{M}$ primer, $0.4 \mu \mathrm{L}$ Taq polymerase $(5 \mathrm{U}), 19.2 \mu \mathrm{L}$ ddH2O and $3.0 \mu \mathrm{L}$ of DNA of the sample $(100 \mathrm{ng} / \mu \mathrm{L})$. Then the samples were performed to RAPD PCR as described before [12]. The electrophoresis of the PCR products was also performed according to the method described by Bozari et. al.[12]. The amplified DNA bands were detected by the BioDoc Image Analysis System with Uvisoft Analysis Package (Cambridge Electronic Design Ltd., Cambridge, UK.) and evaluated by using computer software (TotalLab TL120 v.2009). Genomic template stability was calculated for each primer by using the following formula (GTS, \%) GTS $=(1-$ $\mathrm{a} / \mathrm{n})^{*} 100$. The average number of polymorphic bands detected in each sample (a) and the number of total bands in the control (n) were used for calculation. AFLP analysis was performed as per the instructions of the manufacturer (Invitrogen, Life Technologies). The amplification reaction was stopped by the addition of 109 formamide dye, and products were electrophoresed on a $6 \%$ denaturing polyacrylamide gel. Silver staining is used to stain the gels to detect trace amounts of bands [12]. The presence of the bands in the produced gel scored as "1" and absence as " 0 ". The results were evaluated by SPSS V17 statically program and the UPGMA (Unweighted Pair Group Method with Arithmetic Mean) dendrogram was obtained.

\section{SDS-PAGE profile and quantitative analyses of soluble proteins}

The total soluble protein of the samples was determined by using the method described by Bradford (1976). 0.5 
$\mathrm{g}$ of all samples (root and stem of EO-treated and untreated samples) was ground and homogenized in $0.05 \mathrm{M}$ phosphate buffer ( $\mathrm{pH}: 6.5)$. The homogenates were centrifuged at $12000 \mathrm{rpm}$ for $20 \mathrm{~min}$. Bovine Serum Albumin (BSA) was used as standard. Inhibitory rate (IR) $(\%)$ was calculated using the equation: $I R=(1-$ $\mathrm{x} / \mathrm{y}) * 100(\mathrm{y}$ and $\mathrm{x}$ were the average values detected in the control and each sample, respectively). SDS-PAGE of the total protein was performed according to the method described by Shultz et. al.[16] with some modifications [12].

\section{Determination of plant growth regulator levels}

Extractions and purifications were performed according to Battal and Tileklioğlu [17] with little modifications. The frozen samples (2-2.5 g) were powdered in liquid nitrogen. The cold methanol $(80 \%)$ was added to powdered samples and homogenized by using a tissueblender (Jencons). Then, they were stored at $4{ }^{\circ} \mathrm{C}$ for 24 $\mathrm{h}$ in the dark and filtered through a filter paper (Whatman No.1). The supernatants were again filtered through a PTFE filter $(0.45 \mu \mathrm{m})$ and concentrated at $35^{\circ} \mathrm{C}$ by evaporation. The samples were re-dissolved in $0.1 \mathrm{M} \mathrm{KH}_{2} \mathrm{PO}_{4}$ buffer $(\mathrm{pH} 8.00$ ) and centrifuged at 10.000 for $1 \mathrm{~h}$ at $4{ }^{\circ} \mathrm{C}$. The supernatants were mixed $1 \mathrm{~g}$ polyvinyl polypyrrolidone (PVPP, Sigma Chemical Co, Dorset, UK) and filtered through Whatman No.1 [21]. The filtrates were passed through Sep-Pak C18 (Waters Hichrom Ltd., Berkshire, UK) cartridges. Cartridge adsorbing plant growth regulator were collected eluated with $80 \%$ methanol and the extracts were collected in vials. Then, the samples were analyzed to detect gibberellic acid (GA), zeatin (ZA), indole acetic acid, abscisic acid (ABA) levels [18, 19].

\section{Cytological analysis}

Root tips (1.5 cm long) were excised from germinating seeds, directly fixed in Farmer's fixative and macerated in $1 \mathrm{~N} \mathrm{HCl}$ for $15 \mathrm{~min}$, at $60^{\circ} \mathrm{C}$. The macerated tips were washed with distilled water and stained with acetoorsein $(2 \%)$ and cytological preparations were carried by using Feulgen's squash technique [20]. Well spread plates from at least 20 meristems per replication were scored for each treatment for various types of cytological effects. Microscopic observations were made with a light microscope (LEICA DM-500 of $10 \mathrm{x}$ 40) and by using 100 magnifications. Mitotic index (MI) was calculated using the following formula:

$\mathrm{MI}=[\mathrm{a} /(\mathrm{a}+\mathrm{b})]^{*} 100$

where $a$ is the number of dividing cells and $b$ is the number of non-dividing cells. The data were analyzed according to Duncan's new multiple range test of significance.

\section{RESULTS and DISCUSSION}

The most crucial point before discussing the data presented in this study is that allelopathy, which is related to plant-organism interactions, is not a one-way communication between the two. The natural conditions differ from a laboratory. Microbial fauna, ecological circumstances, and soil characteristics are critical during allelopathic interactions. In addition to external factors, the phenological age, tolerance threshold, and genetic content of the host plants can also affect the allelopathy potential [21]. During the experimental applications, the possible effects of some of these factors were not counted. The analytical results indicated that $M$. longifolia species extract mostly contains monoterpenes and diterpenes such as piperitenon derivatives, pulegon like monoterpenes, and caryophyllene derivative sesquiterpenes. The seed germination rates of maize was reduced in a dose-dependent manner. Although the mitotic index ratio was not important among the control, 0.1 , and $0.2 \mu \mathrm{L} / \mathrm{mL}$ concentrations, but 0.4 and 0.8 $\mu \mathrm{L} / \mathrm{mL}$ concentrations were separated significantly from the control by reducing to $\% 12.5$ ve $\% 12.7$ rates, respectively (Table 1).

Table 1. Mitotic division percentages calculated from root tips of Zea mays L. with applying of essential oil of $M$. longifolia

* Determined by Duncan multiple comparison test at 5\% significance level.

\begin{tabular}{cc}
\hline Concentrations & $\begin{array}{c}\text { Mitotic Index } \\
\text { M. longifolia }\end{array}$ \\
Control & $\mathbf{1 9 . 3}^{\mathrm{a}^{*}}$ \\
$0.1 \mu \mathrm{L} / \mathrm{mL}$ & $19,1^{\mathrm{a}}$ \\
$0.2 \mu \mathrm{L} / \mathrm{mL}$ & $18.0^{\mathrm{a}}$ \\
$0.4 \mu \mathrm{L} / \mathrm{mL}$ & $12.5^{\mathrm{b}}$ \\
$0.8 \mu \mathrm{L} / \mathrm{mL}$ & $12.7^{\mathrm{b}}$ \\
Average & $\mathbf{1 6 . 3}$ \\
$* * \mathrm{CV} \%$ & 6.7 \\
\hline
\end{tabular}

$* * \mathrm{Cv}$ : Coefficient of Variation

There is no significant difference between samples expressed with the same letter in the same column $(\mathrm{P}<0.05)$

Although the low germination and division rates, the highest RAPD based polymorphism was identified in $0,1 \mu \mathrm{L} / \mathrm{mL}$ concentration against the expected results. While the dose-dependent polymorphism decreased, the GTS was normalized by increasing as dose-dependent like $64.13 \%, 67.39 \%, 70.65 \%$, and $75 \%$ respectively. At this moment, it was observed that the RAPD results did not support the previous parameters (Table 2, Figure 1).

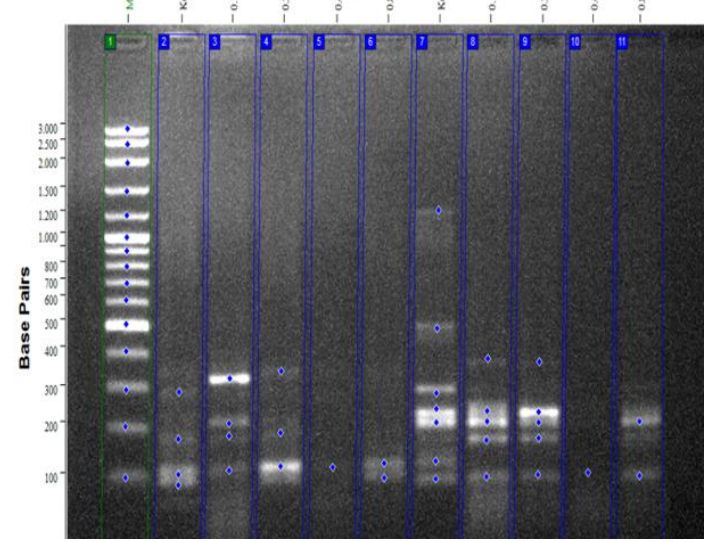

Figure 1. Amplification products of DNA samples from maize seeds to which essential oils from M. longifolia were applied against primers OPY-15 and OPY-16 
Table 2. The number of bands in control and molecular size of (base pair) disappearance (-) and/or appearance $(+)$ of DNA bands for all primers in the EO-treated maize seedlings

\begin{tabular}{|c|c|c|c|c|c|c|}
\hline \multirow[t]{2}{*}{ Primer } & \multicolumn{6}{|c|}{ M. longifolia } \\
\hline & \multicolumn{2}{|c|}{ Control } & \multirow[t]{2}{*}{$\begin{array}{c}\mathbf{0 , 1} \\
\mu \mathrm{L} / \mathrm{mL}\end{array}$} & $\begin{array}{c}\mathbf{0 , 2} \\
\mu \mathrm{L} / \mathrm{mL}\end{array}$ & $\begin{array}{c}\mathbf{0 , 4} \\
\mu \mathrm{L} / \mathrm{mL}\end{array}$ & $\begin{array}{c}\mathbf{0 , 8} \\
\mu \mathrm{L} / \mathrm{mL}\end{array}$ \\
\hline \multirow[t]{2}{*}{ OPA-13 } & 5 & + & & 357 & 357 & \\
\hline & & - & 462 & 462 & 462 & 462 \\
\hline \multirow[t]{2}{*}{ OPH-17 } & 7 & + & ND & 140 & ND & 140 \\
\hline & & - & 387 & ND & ND & ND \\
\hline \multirow[t]{2}{*}{ OPA-2 } & 6 & + & ND & ND & 286 & 286 \\
\hline & & - & 384 & 384 & 384 & 384 \\
\hline \multirow[t]{2}{*}{ OPA-1 } & 7 & + & ND & ND & ND & ND \\
\hline & & - & 404 & $404 ; 61$ & $\begin{array}{l}404 ; 32 \\
1\end{array}$ & 404 \\
\hline \multirow[t]{2}{*}{ OPA-6 } & 2 & + & 479 & ND & ND & ND \\
\hline & & - & 338 & ND & ND & ND \\
\hline \multirow[t]{2}{*}{ OPH-14 } & 4 & + & 421 & 421 & 421 & 421 \\
\hline & & - & 110 & 110 & 110 & 110 \\
\hline \multirow[t]{2}{*}{ OPH-18 } & 7 & + & ND & ND & ND & ND \\
\hline & & - & $282 ; 81$ & $282 ; 81$ & $282 ; 81$ & $282 ; 81$ \\
\hline \multirow[t]{2}{*}{ OPY-6 } & 6 & + & 386 & 386 & ND & ND \\
\hline & & - & 114 & 114 & 114 & ND \\
\hline \multirow[t]{2}{*}{ OPY-1 } & 7 & + & ND & 490 & ND & ND \\
\hline & & - & 308 & 308 & ND & ND \\
\hline \multirow[t]{2}{*}{ OPY-8 } & 7 & + & ND & ND & ND & ND \\
\hline & & - & 428 & 428 & 428 & $\begin{array}{l}428 ; 308 ; 2 \\
03\end{array}$ \\
\hline \multirow[t]{2}{*}{ OPY-15 } & 1 & + & 328 & 345 & ND & ND \\
\hline & & - & $\begin{array}{l}208 \\
294 ; 85\end{array}$ & 294 & $\begin{array}{l}294 ; 17 \\
0 ; 85\end{array}$ & $294 ; 170$ \\
\hline \multirow[t]{4}{*}{ OPY-16 } & 6 & + & $378 ; 16$ & $378 ; 168$ & & 168 \\
\hline & & - & 8 & $1257 ; 484$ & $1257 ; 4$ & 1257; 484; \\
\hline & & & $1257 ; 4$ & $; 291 ; 128$ & 84;291; & $291 ; 248 ; 1$ \\
\hline & & & $84 ; 291$ & & 128 & 28 \\
\hline \multirow[t]{2}{*}{ OPW-1 } & 5 & + & ;128 & ND & ND & 324 \\
\hline & & - & $\begin{array}{l}184 ; 15 \\
9 ; 138\end{array}$ & $184 ; 159$ & $\begin{array}{l}184 ; 15 \\
9\end{array}$ & $184 ; 159$ \\
\hline \multirow[t]{3}{*}{ OPB-8 } & 9 & + & ND & ND & ND & ND \\
\hline & & - & ND & $341 ; 217$ & $341 ; 21$ & ND \\
\hline & & & & 132 & $7 ; 132$ & \\
\hline \multirow[t]{3}{*}{ OPW-7 } & 5 & + & $494 ; 28$ & $494 ; 289$ & $494 ; 28$ & ND \\
\hline & & - & $9 ; 183$ & ND & 9 & ND \\
\hline & & & 313 & & ND & \\
\hline \multirow[t]{2}{*}{ OPW-5 } & 8 & + & 521 & ND & 521 & ND \\
\hline & & - & ND & ND & ND & ND \\
\hline $\begin{array}{l}\text { Total } \\
\text { bands }\end{array}$ & 92 & & 33 & 30 & 27 & 23 \\
\hline \multicolumn{2}{|c|}{$\begin{array}{l}\text { Polimorphism } \\
\text { ratio }\end{array}$} & & 45,87 & 32,61 & 29,35 & 25 \\
\hline \multicolumn{2}{|c|}{ GTS ratio } & & 64,13 & 67,39 & 70,65 & 75 \\
\hline
\end{tabular}

Based on the dendrogram which was obtained from AFLP analyses (Figure 2), it was monitored that 0.4 and $0.8 \mu \mathrm{L} / \mathrm{mL}$ concentrations exhibited one single group identified with the closest concentration amounts.
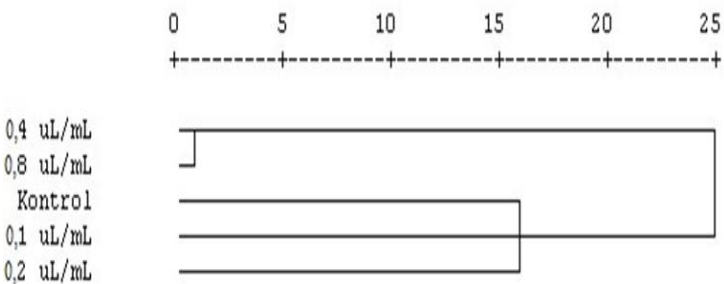

Figure 2. Affinity ratios between Zea mays L. seedlings that applied at different concentrations of M. longifolia essential oils
The control and other concentrations, however, have been identified as the other highly related groups. In addition, 0.4 and $0.8 \mu \mathrm{L} / \mathrm{mL}$ concentrations were identified as the closest concentrations with a ratio of 0.445 based on the similarity index (Table 3 ).

Table 3. Genetic similarity index between seeds of Zea mays L. to which essential oils of M. longifolia were applied

\begin{tabular}{lccccc}
\hline $\begin{array}{l}\text { Cons. } \\
\boldsymbol{\mu L} / \mathbf{m L}\end{array}$ & Control & $\mathbf{0 . 1}$ & $\mathbf{0 . 2}$ & $\mathbf{0 . 4}$ & $\mathbf{0 . 8}$ \\
\hline Control & 1.000 & & & & \\
$\mathbf{0 . 1}$ & 0.359 & 1.000 & & & \\
$\mathbf{0 . 2}$ & 0.356 & 0.353 & 1.000 & & \\
$\mathbf{0 . 4}$ & 0.293 & 0.306 & 0.342 & 1.000 & \\
$\mathbf{0 . 8}$ & 0.272 & 0.273 & 0.333 & 0.445 & 1.000 \\
\hline
\end{tabular}

The furthest concentration to the control was $0.8 \mu \mathrm{L} / \mathrm{mL}$ with a ratio of 0.272 . According to these results, it can be concluded that the AFLP results did not support the RAPD analyses completely, contrast germination rates and mitotic index. On the other hand, the dissolved protein amounts in root cells increased compared to control group. However, this increase was not dose dependent. From stem samples, the dose-dependent decreases were observed as related to other concentrations, except $0.1 \mu \mathrm{L} / \mathrm{mL}$ (Table 4).

Table 4. Total soluble protein in the root and stem of Zea mays seedlings after the application of essential oil ID Cons. $[\mu \mathrm{g} / \mu \mathrm{L}]$

\begin{tabular}{lcccc}
\hline & Root & IR* $^{*}$ & Stem & IR $^{*}$ \\
Control & $52.20^{\mathrm{a}}$ & 0 & $54.00^{\mathrm{b}}$ & 0 \\
$\mathbf{0 . 1} \boldsymbol{\mu L} / \mathbf{m L}$ & $53.58^{\mathrm{ab}}$ & +2.64 & $54.95^{\mathrm{a}}$ & +1.75 \\
$\mathbf{0 . 2} \boldsymbol{\mu L} / \mathbf{m L}$ & $55.89^{\mathrm{c}}$ & +7.09 & $53.46^{\mathrm{c}}$ & -1 \\
$\mathbf{0 . 4} \boldsymbol{\mu L} / \mathbf{m L}$ & $53.20^{\mathrm{ab}}$ & +1.91 & $52.59^{\mathrm{d}}$ & -2.61 \\
$\mathbf{0 . 8} \boldsymbol{\mu L} / \mathbf{m L}$ & $54.45^{\mathrm{bc}}$ & +4.31 & $52.34^{\mathrm{d}}$ & -3.04 \\
\hline
\end{tabular}

IR: inhibitory rate (\%). Means within each column followed by the same letter are not significantly different at the $p<0.05$ level as determined by Duncan's multiple range test.

The SDS-page protein profiles were in accordance these results and provided informative data supporting other parameters. In particular, root and stem profiles demonstrated predominant changes at $0.4 \mu \mathrm{L} / \mathrm{mL}$ concentrations. The changes were observed as formation of new protein polymers, disappearance, and the changes on the concentration of protein profiles.

In addition, the plant growth regulator levels also showed moderate fluctuations like increases and decreases as dose independent. Specifically, while the first two concentrations of GA decreased compared to control, $0.4 \mu \mathrm{L} / \mathrm{mL}$ concentration was higher than control, but it was normalized back to the control level for $0.8 \mu \mathrm{L} / \mathrm{mL}$ concentration. ZA, IAA, and ABA levels were lower as compared to the control for $0.1 \mu \mathrm{L} / \mathrm{mL}$ concentration, but significantly higher for other concentrations (Table 5, Figure3). 


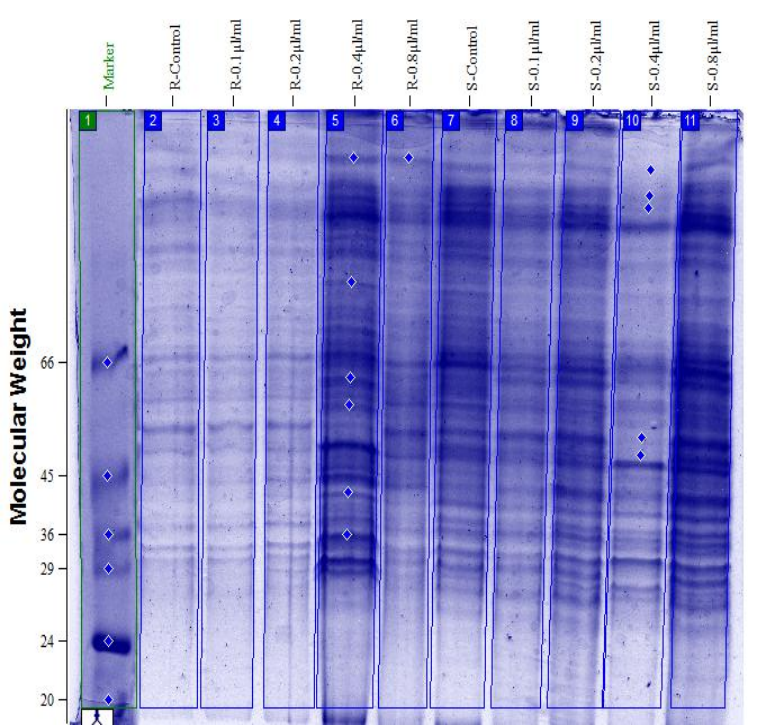

Figure 3. SDS-PAGE protein profiles of maize seeds treated with essential oils from M. longifolia (R: Root, S: Stem; only Marker and a part of polymorphic bands are marked)

Table 5. The changes that occurred at GA, ZA, IAA and ABA

\begin{tabular}{lllll}
\hline & Plant growth promoting & $\begin{array}{l}\text { Plant } \\
\text { growth } \\
\text { inhibiting }\end{array}$ \\
\hline & $\mathrm{GA}$ & $\mathrm{ZA}$ & $\mathrm{IAA}$ & $\mathrm{ABA}$ \\
& $(\mu \mathrm{g} / \mathrm{mL})$ & $(\mu \mathrm{g} / \mathrm{mL})$ & $(\mu \mathrm{g} / \mathrm{mL})$ & $(\mu \mathrm{g} / \mathrm{mL})$ \\
$\mathbf{C o n t r o l}$ & $575.20 \pm$ & $3.20 \pm$ & $36.40 \pm$ & $8.89 \pm 0.05^{\mathrm{e}}$ \\
& $1.27^{\mathrm{d}}$ & $0.05^{\mathrm{a}}$ & $0.11^{\mathrm{b}}$ & \\
$\mathbf{0 . 1} \boldsymbol{\mu L} / \mathbf{m L}$ & $398.31 \pm$ & $2.92 \pm$ & $30.94 \pm$ & $7.41 \pm 0.20^{\mathrm{d}}$ \\
& $0.23^{\mathrm{a}}$ & $0.23^{\mathrm{a}}$ & $0.23^{\mathrm{a}}$ & \\
$\mathbf{0 . 2} \boldsymbol{\mu L} / \mathbf{m L}$ & $405.99 \pm$ & $4.11^{\mathrm{a}} \pm$ & $44.51 \pm$ & $9.70 \pm 0.23^{\mathrm{c}}$ \\
& $0.51^{\mathrm{b}}$ & $0.30^{\mathrm{b}}$ & $0.35^{\mathrm{d}}$ & \\
$\mathbf{0 . 4} \boldsymbol{\mu L} / \mathbf{m L}$ & $641.50 \pm$ & $4.60 \pm$ & $53.90 \pm$ & $16.27 \pm$ \\
& $0.28^{\mathrm{e}}$ & $0.11^{\mathrm{b}}$ & $0.10^{\mathrm{e}}$ & $0.27^{\mathrm{b}}$ \\
$\mathbf{0 . 8} \boldsymbol{\mu L} / \mathbf{m L}$ & $468.59 \pm$ & $6.09 \pm$ & $43.37 \pm$ & $13.31 \pm$ \\
& $0.57^{\mathrm{c}}$ & $0.05^{\mathrm{c}}$ & $0.06^{\mathrm{c}}$ & $0.05^{\mathrm{a}}$ \\
\hline
\end{tabular}

level with applying of essential oil of $M$. longifolia

* In the same column, the same character expressed that there is no significant differences between the samples $(\mathrm{P}<0,05)$.

The decreases were observed in plant growth regulators levels during the EO treatments. At first, it could be explained by seeds-related stress conditions. On the other hand, it has been hypothesized for the following high concentrations that the germinating seeds employ their inherent homeostatic regulations to avoid these adverse situations by doing so neutralize the plant growth regulator conditions back to regular levels.

In the literature, it could be encountered with enormous amounts of publication related to $M$. longifolia species. The different extracts obtained from this species were used for various experiments and identified as potential mutagenic, co-mutagenic, and antimutagenic effects [22] According to some previous experiments, different extracts were identified with their activities such as cytotoxic activity, inhibition effect on seed germination of tested plants, substantial herbicide potential by inhibiting the seed germination, blocking the plasma membrane $\mathrm{Ca}^{2+}$ channels and eliminating the toxic free radicals $[23,24]$. It was observed that P-cymene or $\alpha$ - terpinene and carvacrol have shown synergistic effects and inhibited seed germination on test plants [25]. It is possible to consider the synergistic and antagonistic interactions together with the total allelopathic effects of volatiles. It could be concluded that the content of volatile lipids of $M$. longifolia demonstrated harmony with the results from previous studies indicated quantitative variations due to the regional and genetic differences. It is hard to mention a specific cellular target for entire volatile lipid contents since they contain many different compounds. When the volatile content was analyzed for each compound as singular, it could be observed that their effects can vary specifically. For instance, it was reported from previous studies that the piperitone derivatives, the most common monoterpene in M. longifolia, trigger cellular deformations [26]. It could be also stressed that these compounds could easily pass-through the plasma membrane and change the membrane permeability and affect the protoplasmic content adversely. Terpenoids which differ chemically and functionally most likely overcome various characteristics in metabolic reactions. GA and $\mathrm{ABA}$ type terpenes are included in $\mathrm{C}_{5}-\mathrm{C}_{20}$ group-terpenes as similar to monoterpenes, diterpenes, and sesquiterpenes and essential for propagation, growth, and defense systems [27]. Therefore, the contents of volatile lipid comprising such terpenoids could also reveal similar effects on plant growth regulators mentioned above. As Schempp et al. [28] has underscored that allelochemicals are one of the biological stress factors.

In general, plants develop stress conditions when they are treated with or exposed to these chemicals and initiate various mechanisms such as avoidance, adaptation, and defense-related which resulted in physiological alterations in plant metabolic activity. It is well known that allelochemicals inhibit the biosynthesis of metabolically vital enzymes and proteins by adverting the expression of specific genes in target plants. It is also accepted that caryophyllene and its derivatives can reveal mutagenic and antimutagenic effects at different extents through binding specific receptors. In parallel, the alterations occurring in nucleotide base profiles of genomic DNA can stem from deletion, insertion or priming based modifications. In addition, the variations in RAPD profiles could be explained by stress conditions caused by the volatile lipid content applied to tested plants. The fact that the GTS values approach to control levels with increasing concentrations could be explained as the reasons for mutations at low concentrations of volatile lipids applied. The high levels of concentrations, however, could trigger antimutagenic effects on the plants encountered with diverse conditions. The chemical composition and quantities of the volatile lipids may also affect the experimental results through dosedependent applications. For instance, intercellular redox potentials and mitochondrial malfunctioning in cells may stem from the adverse effects of the variable contents of volatile lipids. The AFLP profiles identified 
more different than RAPD results point out that the genomic DNA manipulations could arise not only from mutations but also epigenetic modifications such as DNA methylation-based gene silencing. The increasing amounts of soluble proteins in root cells as compared to control could be evaluated as the possible reactions of plants against stress conditions. The increases in the amounts of prolin amino acids in plants as a reaction to various stress conditions can be given as a remarkable example of this situation. This plant-based reaction is primarily a defense-intended adaptation against adverse environmental parameters which could differ from plant to plant. It was also identified that while the soluble proteins in root samples increased, the stem samples showed reverse tendency. The large quantities of inhibition identified in SDS-PAGE profiles as similar to previous parameters could be explained as plausible results of the variations that occurred on the nonfunctional regions of genomic DNA. Decomposition of the total oil and application of each substance individually will allow us to know the target close effects.

\section{ACKNOWLEDGEMENTS}

This study was supported by Ataturk University BAP (2010/271) head office as a part of the corresponding author's $\mathrm{PhD}$ thesis.

\section{REFERENCES}

[1] Fletcher J., Bender C., Budowle B., Cobb W., Gold S., Ishimaru C., Luster D., Melcher U., Murch R., Scherm H. Plant pathogen forensics: capabilities, needs, and recommendations, Microbiol. Mol. Biol. Rev., 70:2 450471, 2006.

[2] Sodaeizadeh H., Rafieiolhossaini M., Van Damme P. Herbicidal activity of a medicinal plant, Peganum harmala L., and decomposition dynamics of its phytotoxins in the soil, Indust. Crops Prod., 31:2 385394, 2010.

[3] Bozari S., Agar G., Aksakal O., Erturk F.A., Yanmis D. Determination of chemical composition and genotoxic effects of essential oil obtained from Nepeta nuda on Zea mays seedlings, Toxicol. Industr. Health, 29:4 339348, 2013.

[4] Gormez A., Bozari S., Yanmis D., Gulluce M., Agar G., Sahin F. Antibacterial activity and chemical composition of essential oil obtained from Nepeta nuda against phytopathogenic bacteria, J. Essent. Oil Res., 25:2 149153, 2013.

[5] Cordell G.A. Biodiversity and drug discovery-a symbiotic relationship, Phytochemistry, 55:6 463-480, 2000.

[6] Kobayashi K., Itaya D., Mahatamnuchoke P., Pornprom T. Allelopathic potential of itchgrass (Rottboellia exaltata L.) powder incorporated into soil, Weed Biol. Manag., 8:1 64-68, 2008.

[7] Heywood V.H., Flowering plants of the world, BT Batsford Ltd, 1993.

[8] Castro-Vázquez L., Díaz-Maroto M., González-Viñas M., Pérez-Coello M. Differentiation of monofloral citrus, rosemary, eucalyptus, lavender, thyme and heather honeys based on volatile composition and sensory descriptive analysis, Food Chem., 112:4 1022-1030, 2009.

[9] Ben Farhat M., Jordán M.a.J., Chaouech-Hamada R., Landoulsi A., Sotomayor J.A. Variations in essential oil, phenolic compounds, and antioxidant activity of tunisian cultivated Salvia officinalis L., J,Agri. Food Chem., 57:21 10349-10356, 2009.

[10] Cheung S., Tai J. Anti-proliferative and antioxidant properties of Rosmarinus officinalis, Oncol. Rep., 17:6 1525-1532, 2007.

[11] Takaki I., Bersani-Amado L., Vendruscolo A., Sartoretto S., Diniz S., Bersani-Amado C., Cuman R. Antiinflammatory and antinociceptive effects of Rosmarinus officinalis L. essential oil in experimental animal models, J.Medic. Food, 11:4 741-746, 2008.

[12] Bozari S. Determination of the Genotoxic Effects of the Potential Allelopathic Essential Ois Obtained from Various Species of Lamiaceae Family, PHD, Biology, Atatürk Üniversity, 2012.

[13] Oyedeji A., Afolayan A. Chemical composition and antibacterial activity of the essential oil isolated from South African Mentha longifolia L. subsp. capensis (Thunb.) Briq., The J. Essent.l Oil Res., 18: 57-59, 2006.

[14] Mimica-Dukic N., Popovic M., Jakovljevic V., Szabo A., Gašic O. Pharmacological studies of Mentha longifolia phenolic extracts. II. Hepatoprotective activity, Pharma. Biol., 37:3 221-224, 1999.

[15] Liu W., Li P., Qi X., Zhou Q., Zheng L., Sun T., Yang Y. DNA changes in barley (Hordeum vulgare) seedlings induced by cadmium pollution using RAPD analysis, Chemosphere, 61:2 158-167, 2005.

[16] Shultz R.W., Settlage S.B., Hanley-Bowdoin L., Thompson W.F. A trichloroacetic acid-acetone method greatly reduces infrared autofluorescence of protein extracts from plant tissue, Plant Mol. Biol. Rep., 23:4 405-409, 2005.

[17] Battal P. Tileklioğlu B. The effects of different mineral nutrients on the levels of cytokinins in maize (Zea mays L.), Turk. J.Bot., 25: 123-130, 2001.

[18] Cetin A., Bozari S. Study on the Synthesis, Antimicrobial Activity, and Rapd Analysis of 3-phenyl1,5-bis(4-(trifluoromethyl)phenyl)-1H-pyrazole, J Biochem Tech., 11:3, 77-83.

[19] Morris J.W., Doumas P., Morris R.O., Zaerr J.B. Cytokinins in vegetative and reproductive buds of Pseudotsuga menziesii, Plant Physiol., 93:1 67-71, 1990.

[20] Türker M., Battal P., Aĝar G., Güllüce M., Şahin F., Erez M., Yildirim N. Allelopathic effects of plants extracts on physiological and cytological processes during maize seed germination, Allelopat. J., 21:2 273286, 2008.

[21] Erez M.E. Lepidium draba L., Acroptilon repens (L.) DC., Thymus kotchyanus Boiss\&Hohen. var. kotchyanus, Inula peacockiana (Aitch.\&Hemsl.) Koravin, Salvia kronenburgei Rech. f. ve Phlomis armeniaca Wild. Bitkilerinin Allelopatik etkilerinin Araştrırılması, Doktora Tezi, Biology, Yüzüncü yıl Üniversitesi, 2009.

[22] Orhan F. Mentha longifolia L. Hudson Ssp. Longifolia'dan Elde Edilen Bazı Etken Maddelerin Ames/Salmonella ve Maya Delesyon Test Sistemleri ile Mutajen ve Antimutajen Özelliklerinin Belirlenmesi, phd, Biology, Atatürk Üniversity, 2010.

[23] Ahmad N., Fazal H., Ahmad I., Abbasi B.H. Free radical scavenging (DPPH) potential in nine Mentha species, Toxicol. Indust. Health, 28:1 83-89, 2012.

[24] Shah A.J., Bhulani N.N., Khan S.H., Gilani A.H. Calcium channel blocking activity of Mentha longifolia 
L. explains its medicinal use in diarrhoea and gut spasm, Phytother. Res., 24:9 1392-1397, 2010.

[25] Vokou D., Chalkos D., Karamanoli K., Microorganisms and allelopathy: a one-sided approach, Allelopathy, Springer, 2006

[26] Tripathi A.K., Prajapati V., Ahmad A., Aggarwal K.K., Khanuja S.P. Piperitenone oxide as toxic, repellent, and reproduction retardant toward malarial vector Anopheles stephensi (Diptera: Anophelinae), J.Med. Entomol., 41:4 691-698, 2004.

[27] Thomas S.G., Rieu I., Steber C.M. Gibberellin metabolism and signaling. Vitamins and Hormones, 72: 289-338, 2005.

[28] Schempp H., Hippeli S., Elstner E.F., Hock B. Plant stress: avoidance, adaptation, defense, Plant Toxicol., 4th ed. New York: Marcel Dekker, 87-129, 2005. 